\title{
Japan plans space station in low Earth orbit
}

\section{- National space budget may triple}

\section{- Not one, but two shuttles}

Tokyo

JAPAN has new and optimistic plans to join the United States as a major space power. Two recently released reports see a Japanese space station in low-Earth orbit by 2010 . The reports come from the longterm policy group of the Space Development Committee and the space plane advisory group of the Research and Development Bureau of the Science and Technology Agency. Both have been submitted to the Space Activities Commission, responsible for the nation's space policy, and will be used to draw up plans for 15 years, beginning in 1989.

Japan's present space programme is modest, with an annual budget of only Y130,000 million ( $\$ 1,000$ million). The

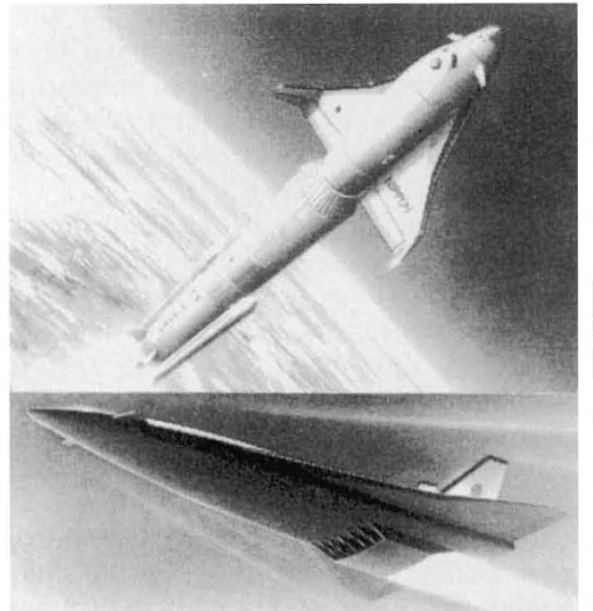

The two shuttles: one for cargo and one for passengers.

long-term policy group calls for a tripling in Japan's space budget. The US space station is central to the proposed programme up to the mid-1980s: Y310,000 million is allotted to the Japanese experimental module for the station, Y480,000 million for a co-orbiting platform and Y120,000 million for an orbital manoeuvrable vehicle, or 'tugboat', to tow the platform to and from the station.

Design of the proposed co-orbiting platform and tugboat would begin in the late 1980s and early 1990s, respectively, and the policy group also calls for development of a polar-orbiting platform for lowEarth orbit at a cost of Y180,000 million.

In the second half of the 1990s, the policy group advocates the development of a manned co-orbiting platform (Y480,000 million), a geostationary platform (Y360,000 million) and an interorbital transport system (Y900,000 million) to link the latter with the space station. It is at this stage that the group foresees entry of Japan's private industry. It calls on the government to encourage private investment of about Y3 million million through tax incentives and attractive government loans to develop, for example, a space factory for new materials.

The most ambitious plans of all, however, call for development of two types of Japanese shuttle costing over Y2 million million and a Japanese space station for a further one million million yen. Development of the proposed station would not begin until 2000 , and can be forgotten about for the moment. But some limited work on the shuttles has already started..

The space plane panel recommends development of an unmanned cargo shuttle called HOPE ( $\mathrm{H}-2$ orbiting plane) to be carried aloft by a modified version of the $\mathrm{H}-2$ rocket, and an air-breathing space plane (like Britain's HOTOL) for manned flight. Two shuttles are advocated because of different priorities: safety is the prime concern for a manned spacecraft, while cost efficiency and large payload are required for a cargo plane.

The Science and Technology Agency's budget for this year includes Y33 million for preliminary study of an air-breathing engine and the panel calls for joint development of the space plane by the agency's National Aerospace Laboratory, the National Space Development Agency, and the Institute of Space and Astronomical Science.

But will the Ministry of Finance be prepared to put up the funds? The six million million yen called for in the 15year plan is not excessive when compared with projected outlays for space during the same period by the US and Europe (Y40 million million and Y13 million million, respectively) and Japan's space budget has been lagging behind growth in the nation's gross national product. But an expenditure of $\mathrm{Y} 2$ million million for shuttle development would be unprecedented.

So is Japan seriously intending to go it alone in building two shuttles? No, says Masahiro Kawasaki, deputy director general of the Research and Development Bureau of the Science and Technology Agency. Japan must commit herself to the development of new technology, he says, so that she can cooperate with other nations on an equal footing.

David Swinbanks

\section{No go for the creationists}

\section{Washington}

THE US Supreme Court has squashed an attempt by the state of Louisiana to require the teaching of "creation science" theory whenever evolution theory is taught. The court ruled that the Balanced Treatment Act violated the First Amendment to the Constitution which states that governments may not make laws "respecting an establishment of religion".

Although the 7-2 ruling applies specifically to Louisiana, it will be a model for all others, making it difficult if not impossible for states to require schools to teach the theory of "creation science".

The court had to decide whether the Louisiana legislature had a secular purpose when it passed the Balanced Treatment Act. Justice William Brennan, writing for the majority, agreed with the lower courts that had ruled that the law's intent was "to discredit evolution by counterbalancing its teaching with the teaching of creationism, a religious belief"

In a lengthy and spirited dissent, Justice Antonin Scalia argued that the state legislature did indeed have a secular purpose in passing the act. Justice Scalia argued that the act "did not fly through the Louisiana Legislature on wings of fundamentalist fervor". He noted that the parade of witnesses supporting the act presented "lengthy, and, to the layman, seemingly expert testimony on the origin of life". Failure to present evidence for the theory of "creation science" would deprive students of a balanced education.

But the majority ruled that arguments for the secular purpose of the act were a sham, only presented post hoc. Rather than enhancing academic freedom, said the majority, the Louisiana law undermines a comprehensive scientific education.

The Balanced Treatment Act was passed in 1981, but was challenged immediately in federal court, and never actually implemented. A similar law had been nullified in Arkansas in 1980 .

Justice Scalia's dissent argued that there were issues of material fact to be determined in the decision about the Louisiana law, and that case should have been sent back to lower courts for a trial. Notably, a trial would serve the purpose of giving a definition to the term "creation science". Justice Scalia expressed astonishment that the court disbelieved Louisiana's secular intent, and attributed this to "an intellectual predisposition created by the facts and the legend of Scopes v. State", a case in 1927 based on a Tennessee law that tried to prohibit the teaching of evolution. Joseph Palca 